Aleksandra Wilkus-Wyrwa

Uniwersytet im. Adama Mickiewicza w Poznaniu

\title{
„Skazani na ciężkie norwidy”? Kilka uwag o kulturowych aspektach przekładu poezji Wisławy Szymborskiej na język norweski
}

\author{
"Skazani na ciężkie norwidy"? Some Remarks about Cultural Aspects \\ of the Norwegian Translation of Wisława Szymborska's Poetry
}

The aim of this paper is to discuss selected cultural keywords in the Norwegian translation of Wisława Szymborska's (1923-2012) poetry. Translators O.M. Selberg and Ch. Kjelstrup used multiple approaches, thanks to which Norwegian readers have a chance to get acquainted with typical Polish phenomena, although often at an expense of the original text. Since the kind of publishing itself - an anthology of translated poetry - indicates the place of Szymborska's work in the foreign discourse, her published works in Norway, Sweden and Denmark, along with her reception in Norwegian discourse as a Nobel Prize winner, are discussed here as well.

Key words: poetry, translation, Szymborska, culture, Norwegian

Słowa klucze: poezja, przekład, Szymborska, kultura, norweski

Przekład literacki od zawsze wzbudzał wśród badaczy-teoretyków wiele kontrowersji - począwszy od terminologii po wybór odpowiednich strategii translatorskich, spośród których jedne będą skłaniać się ku jak najwierniejszemu oddaniu formy oryginału, podczas gdy inne, ukierunkowane na język docelowy, będą dążyć do czytelniczego komfortu nowej grupy odbiorców. Stanisław Barańczak (1946-2014) zwykł używać określenia interpretacja, bo to ona prowadzi ostatecznie do stworzenia analogicznego - analogicznie funkcjonującego - tekstu w innym języku etnicznym (Barańczak 1994: 15). Jedną z wielu trudności podczas tłumaczenia literatury pięknej, a zwłaszcza poezji, jest nieustanne balansowanie pomiędzy wiernością tekstowi wyjściowemu, szeroko rozumianą powinnością a chęcią umożliwienia nowemu gronu odbiorców doświadczenia estetycznego podobnego do tego, jakie wywołuje oryginał. Szczególnie interesujący przypadek stanowi aspekt kulturowy, bo to, co dla tłumacza zdaje się oczywiste, rzadko zostanie rozpoznane także przez czytelników w języku docelowym. 
Dyskusja o obecności Wisławy Szymborskiej w przestrzeni norweskiej, zarówno tej kulturowej, jak i tej ściśle literackiej, wymaga pewnych uzupełnień. Dotychczasowy oddźwięk tej poezji w Norwegii można by mierzyć, co stanowi dość oczywisty punkt odniesienia dla szeroko pojętych badań komparatystycznych, ilością przełożonych na język norweski zbiorów noblistki. Jednakże sam fakt tłumaczenia danego dzieła nie decyduje o jego żywotności w kulturze docelowej, podobnie jak nie jest on wystarczający przy omawianiu wpływu twórczości Szymborskiej na tamtejszych pisarzy. By zwrócić uwagę na to, jak szerokie kręgi zatacza artystyczny dialog między Polską a Norwegią, należy nieco bliżej przyjrzeć się roli dwóch omówionych poniżej antologii. Jednocześnie warto przy tej okazji poruszyć jedną z ważniejszych kwestii związanych z przekładem, mianowicie wspomniany już kulturowy wymiar tekstu literackiego. Taka perspektywa rzuca bowiem nowe światło na konstytuowanie się danej sylwetki pisarskiej w nowej - nie tylko językowej - przestrzeni, która w tym artykule obejmuje również Szwecję i Danię.

Niniejsza analiza jest owocem pracy doktorskiej (Wilkus-Wyrwa 2019) ${ }^{1}$, której celem było zbadanie możliwości oddania w przekładzie immanentnych cech estetycznych danego twórcy. Dlatego właśnie punkt wyjścia stanowią tu typowe dla liryki Wisławy Szymborskiej środki stylistyczne, figury retoryczne, motywy czy obrazy językowe, osadzone w konkretnym kontekście kulturowym oraz w określonej tradycji literackiej. Literatura krytyczna dotycząca twórczości noblistki przypomina natomiast studnię bez dna. $Z$ tego względu lapidarnie omówię tu poszczególne zjawiska, skupiając się przede wszystkim na tych elementach, które mają kluczowe znaczenie dla ostatecznej formy danego tłumaczenia. To swego rodzaju paradoks, biorąc pod uwagę stosunkowo niewielką objętościowo twórczość poetki oraz ilość prac napisanych na tej podstawie. Musimy mieć jednak świadomość, że jako polskojęzyczni odbiorcy tej poezji pozostajemy w sytuacji mocno uprzywilejowanej. Kto, jak nie biegle posługujący się językiem polskim czytelnik, będzie w stanie rozszyfrować subtelne gry intertekstualne czy semantyczne Szymborskiej?

\section{Szymborska w i na językach}

Omawiane tu teksty pochodzą z dwóch opublikowanych po norwesku zbiorów poezji noblistki - Utsikt med et sandkorn (Widok z ziarenkiem piasku, 1996) oraz Livet er den eneste måten (Życie jest jedynym sposobem, 2013). Za pierwszą z antologii odpowiada Ole Michael Selberg (1938-), slawista, wybitny znawca języka polskiego i jeden $\mathrm{z}$ najważniejszych tłumaczy literatury polskiej, natomiast

$1 \quad$ Dysertacja Wilkus-Wyrwa 2019 powstała w oparciu o system cotutelle na mocy współpracy między Uniwersytetem Adama Mickiewicza a Uniwersytetem w Agder. 
przekładu² tekstów z okresu 2002-2012 podjął się krytyk literacki, redaktor oraz dziennikarz Christian Kjelstrup. Mimo iż twórczość Szymborskiej reprezentowana jest w Norwegii przez zaledwie dwa w całości poświęcone jej poezji wydawnictwa, ich przekrojowy charakter umożliwia zapoznanie się z największą i bodaj najważniejszą częścią dorobku autorki. Utsikt med et sandkorn składa się z 60 wierszy. Jest to autorski wybór Selberga, który - wzorując się na polskim, lecz o wiele obszerniejszym tomiku Widok z ziarenkiem piasku (1996) - zaprezentował utwory $\mathrm{z}$ lat 1957-1993. Kjelstrup przełożył natomiast cztery pełne tomy poetyckie, w tym Chwile (Øyeblikket; wyd. polskie 2002) i ostatnią wydaną za życia noblistki pozycję Wystarczy (Nok; wyd. polskie 2012). Z punktu widzenia przekładoznawstwa to cenne informacje, ponieważ już sama struktura oraz charakter antologii dzieł tłumaczonych ${ }^{3}$ wyznaczają krytykom nowe perspektywy badawcze. Nietrudno zauważyć, że zarówno antologie bilateralne, tj. obejmujące jeden język lub jeden krąg kulturowy, jak i multilateralne, które reprezentują różne kraje przyporządkowane konkretnym kategoriom (Chojnowski 2005: 42), przyczyniają się z jednej strony do ugruntowania kanonu (Frank, Eßmann 1990: 23), a z drugiej do poszerzenia wiedzy o literaturach narodowych (Lothe, Refsum 1997: 18). Jeśli więc dane wydawnictwo cechuje spójność koncepcji tematycznej czy gatunkowej wraz $\mathrm{z}$ odpowiednimi paratekstami, w tym z tytułem, szatą graficzną oraz opracowaniem utworów tłumaczonych (Pforte 1970: XXV), taka antologia ma szansę stać się ważnym głosem w literackiej historiografii o mikrozasięgu (Baubeta 2007: 14), mając na myśli skalę kraju docelowego. Choć powyższe uwagi wskazują przede wszystkim na pragmatyczny wymiar tworzenia antologii, to właśnie one - nie zapominając o jakości tłumaczenia - decydują o żywotności danej twórczości w kulturze docelowej.

Oczywiście niebagatelny wkład w umacnianiu recepcji obcego autora ma krytyka literacka, ale jeśli mówimy o propagowaniu liryki Szymborskiej w Norwegii, warto zwrócić uwagę na dwa nazwiska, mianowicie znamienitego saksofonisty Jana Garbarka4 (1947-) oraz poety Jana Erika Volda (1939-). Garbarek, którego

2 Kjelstrup przyznaje, że podczas tłumaczenia poezji Szymborskiej na norweski opierał się głównie na języku rosyjskim (studiował rosyjski w Oslo i Petersburgu). Mimo że sam nie mówi po polsku, opanował rozumienie pisma na tyle dobrze, by móc podjąć się tego zadania. Jak podkreśla w jednym z wywiadów, równoczesna praca z oryginałami oraz przekładami na rosyjski, niemiecki i angielski otworzyła przed nim szersze perspektywy, a także pozwoliła uniknąć wielu błędów zauważonych u swoich poprzedników (Fyllingsnes, Kjelstrup 2013: 12-13).

3 Mamy tu na myśli specyficzną kategorię wydawniczą, określaną przez niemieckich przekładoznawców mianem „Übersetzungsanthologie”, a więc pozycję zawierającą wybór tekstów obcych autorów w przekładzie (por. Eßmann 1992).

4 Warto nadmienić, że Jan Garbarek ma polskie korzenie. Jego ojciec, Czesław Garbarek, został deportowany do Norwegii podczas drugiej wojny światowej, gdzie początkowo pracował na kolei w regionach Nordland oraz Trøndelag. Tam też poznał swoją żonę Kari Nordbø (później 
twórczość noblistki zainspirowała do nagrania albumu In Praise of Dream (2004), mówił o Szymborskiej: „Jest coś wewnątrz tej poezji, co dociera do mnie, coś, co trafia spontanicznie, coś, co od razu pokochałem. Znałem jej dzieła jeszcze przed Nagrodą Nobla, więc ta fascynacja nie wypłynęła na fali jej popularności związanej z tym laurem" (Januszewska-Skreiberg 2011: 168). Z kolei Vold poświęcił Szymborskiej dużo miejsca w swojej eseistycznej książce o wybitnych poetach pt. Storytellers. En begrunnet antologi (Opowiadacze. Zasłużona antologia), gdzie prócz krótkiej biografii autorki i lapidarnych szkiców kilku wierszy znajdziemy również takie słowa: „Nieśmiała, refleksyjna, przenikliwa, mądra. Zdystansowana - dlatego nigdy rozżalona. Bystra - dlatego zawsze taktowna” (Vold 1998: 177). Norweski poeta wskazuje także na osobliwy związek między lakonicznym językiem Szymborskiej a jej niemal czarodziejską sztuką kreowania rzeczywistości (Vold 1998: 172). Zauroczenie Volda zaowocowało umieszczeniem utworu Rozmowa $z$ kamieniem (Samtale med en stein, tłum. O.M. Selberg) na płycie Storytellers (1998) melorecytacji wiersza towarzyszy tu muzyka autorstwa Nissego Sandströma i Egila Kapstada. Ślady obecności Szymborskiej znaleźć można ponadto u Marion Berntzen Koksvik (1939-), zwłaszcza w tomach Elegi for Dagny Juel (Elegia dla Dagny Juel, 1997) i Stjerne for en liten klode (Gwiazdka dla małej planety, 1998), a także u Bergljot Hobæk Haff ${ }^{5}$ (1925-2016). Od ostatniego wydania tomiku z poezją noblistki upłynęło wprawdzie sześć lat, ale Kjelstrup, Selberg, Vold i tłumaczka polskiej literatury na norweski, Agnes Banach (1980-), nie dali publiczności zapomnieć o Szymborskiej. Za zdarzenie o przełomowym znaczeniu dla recepcji jej dzieł w Norwegii należy bowiem uznać spektakl pt. Życie jest jedynym sposobem (Livet er den eneste måten) w reżyserii Josa Groeniera. Premiera miała miejsce 1 lutego 2019 roku na deskach Teatru Narodowego (Nationaltheatret) w Oslo. Scenariusz opiera się na wierszach i innych tekstach poetki przy dźwiękach muzyki skomponowanej przez Kjetila Bjerkestranda (1955-) i Jana Garbarka, a wszystkie wykorzystane w przedstawieniu fragmenty wyświetlane były dodatkowo po polsku. Premierze towarzyszył również cały szereg innych wydarzeń, w tym wystawa kolaży Szymborskiej oraz seminarium poświęcone jej twórczości.

Najważniejszą rolę w popularyzowaniu twórczości Szymborskiej na rynku skandynawskim odegrali jednak tłumacze ze Szwecji ${ }^{6}$, między innymi Nils Åke

Garbarek). „Czek”, jak zwykli go nazywać Norwegowie, otrzymał później norweskie obywatelstwo i przez wiele lat pełnił funkcję kierownika Biblioteki Wydziału Fizyki przy Uniwersytecie w Oslo (por. Dybdo 1996; Morken 2015).

5 Więcej o inspiracji Haff pisze Janina Januszewska-Skreiberg (2001).

6 Pierwsze tłumaczenia pojedynczych utworów Szymborskiej ukazały się w Szwecji za sprawą Nilsa Åke Nilssona (antologia poezji polskiej pt. Det nakna ansiktet/Naga twarz) w roku 1960. Pięć lat później kolejnych kilku tłumaczeń dokonał Erik Mesterton (czasopismo Horisont 1965, nr 4-5). Pierwszy szwedzkojęzyczny tom w całości poświęcony poezji Szymborskiej opublikowano natomiast w 1980 roku (Nigdy dwa razy/Aldrig två gånger, tłum. Per-Arne Bodin i Roger Fjellström). 
Nilsson (1917-1995), Per-Arne Bodin (1949-) i znany polskim czytelnikom Anders Bodegård (1944-). Jako że Bodegård przełożył największą część jej dorobku, a rzadko które tłumaczenia doczekały się współcześnie tak pochlebnej krytyki, sama Szymborska na wieść o przyznaniu jej Nobla zakrzyknęła: „To wina Andersa!” (Bodegård 2014: 28). Bodegård niejednokrotnie zabierał także głos w dyskusjach o stylu pisarstwa Szymborskiej, chociażby formułując ciekawą tezę, w której estetykę tę określa mianem „trzech i-" - idiom, iluzja, ironia ${ }^{7}$ (Bodegård, Nowicka 2012). Jako rzemieślnik języka i sztuki zarazem zwrócił również uwagę na niezwykłą lekkość, taneczność, figlarność oraz łagodność tej poezji. Być może właśnie tego rodzaju translatorska wrażliwość zagwarantowała Bodegårdowi miejsce wśród najwybitniejszych tłumaczy Szymborskiej (Neuger 1991: 98). W Danii polska poetka zaistniała z kolei dzięki pisarce i tłumaczce Janinie Katz (19392013). W 1982 roku na rynku pojawiła się książka Lots hustru og andre kvinder. Digte (Żona Lota i inne kobiety. Wiersze), nad którą Katz pracowała wspólnie z znamienitą pisarką, poetką oraz eseistką Inger Christensen (1935-2009). Wydanie to zostało dodatkowo opatrzone ilustracjami autorstwa słynnej Lene Adler Petersen (1944-). Drugi tom z duńskojęzyczną poezją Szymborskiej pt. En kat i en tom lejlighed (Kot w pustym mieszkaniu, 1996) powstał dzięki połączeniu sił Katz i innego znanego literata - Uffego Hardera (1930-2002).

Jeśli zaś chodzi o Norwegię, Szymborska „zadebiutowała” w przełomowej antologii Den sjuande engelen. Eit utval frå polsk etterkrigslyrikk (Siódmy anioł. Wybór polskiej liryki powojennej, 1967), za którą odpowiadali Arnljot Eggen (1923-2009) oraz Martin Nag (1927-2015). Nag, będący jednocześnie wybitnym slawistą, komparatystą, tłumaczem oraz poetą, opublikował kilka wierszy poetki także w książce Tverr-snitt. Litteraturhistorie, kulturhistorie, prosalyrikk (Prze-krój. Historia literatury, historia kultury, proza liryczna, 1997). Inną ważną postacią, której nie sposób pominąć w tym kontekście, jest Jan Brodal (1939-). Polen forteller (Polska opowiada, 1991) - antologia polskiej prozy w jego opracowaniu stała się kamieniem milowym w przybliżaniu norweskim czytelnikom kanonu literatury polskiej. Kilka wierszy Szymborskiej znaleźć można między innymi w tomie Mosaikk (Mozaika, 1980), na który składa się twórczość własna i przekłady jego autorstwa. W 1982 roku, jeszcze przed zbiorem Utsikt med et sandkorn, Selberg opublikował antologię współczesnej poezji polskiej pt. Tiden er knapp. Du skal vitne (Czasu coraz mniej. Będziesz świadkiem), gdzie zamieszczono część wcześniej przełożonych na norweski utworów noblistki, a także dwa tytuły w innych językach skandynawskich (duńskim i szwedzkim). Nie trudno zgadnąć, że Nagroda Nobla dla Szymborskiej zainspirowała nie tylko do wzmożonej pracy translatorskiej, ale także do zainicjowania szerszej dyskusji o obecności literatury polskiej

W innym artykule Bodegård dodaje jeszcze jedno określenie, mianowicie „imitacja” (por. 2003). 
na rynku skandynawskim. Chociażby $\mathrm{z}$ tego powodu warto jeszcze wspomnieć o społeczno-kulturowym czasopiśmie Ergo, którego jeden z numerów (1996/3) w całości poświęcono tej tematyce. Prócz przekładów Szymborskiej znajdziemy w nim teksty krytyczne między innymi: Jana Brodala, Mieczysława Orskiego, Ole M. Selberga czy Janiny Januszewskiej-Skreiberg.

\section{Kultura a przekład}

Wyzwanie, jakie stanowi przetransponowanie elementów charakterystycznych dla danego języka czy społeczności na zupełnie nowy grunt, towarzyszy nam od samego początku historii tłumaczenia, tj. od ponad 4000 lat (Wojtasiewicz 1957: 7-8). Jednak do dziś, co zresztą dotyczy również innych składowych procesu komunikacji za pomocą przekładu literatury pięknej, nie jesteśmy w stanie zaproponować jednego rozwiązania, które można by uznać za uniwersalne i wyczerpujące, a jednocześnie takie, które gwarantowałoby wysoką jakość tekstu w języku docelowym oraz przychylność wśród jego nowych odbiorców. Choć naukowe zainteresowania tą problematyką rozpoczęły się na dobre już w latach 60 . XX wieku, ponowna fala badań związków kultury z przekładem przypada na lata 90., szczególnie z uwagi na zwrot kultury i działalność takich teoretyków, jak: Homi Bhabha (1949-), Doris Bachmann-Medick (1952-) czy Mary Snell-Hornby (1940-).

W niniejszym artykule pochylamy się nad zaledwie jednym z elementów dzieła literackiego, a tym samym jednym z kilku aspektów, które w sumie decydują o ostatecznej formie przekładu. Sylvia Liseling Nilsson badała literackie manifestacje kultury w tłumaczeniach tekstów Astrid Lindgren, nakreślając przedmiot swojego studium następująco:

Dzieło literackie jest językiem symboli, konotacji poszczególnych słów, wyrażeń i odnośników semantycznych oraz kodu kulturowego. [...] Większość słów i znaków zawiera w sobie pewną zakodowaną informację, która do tego stopnia stanowi część naszej wiedzy kulturowej, że znając otaczającą rzeczywistość, niekiedy w ogóle tego faktu się nie zauważa (Nilsson 2012: 49).

Operując sformułowaniem „kod kulturowy”, odnoszę się do prac teoretycznych Marii Krysztofiak (1946-), według której współistnienie i odpowiednie proporcje kodów: leksykalno-semantycznego, kulturowego oraz estetycznego (2013: 31-69) w tekście przełożonym świadczą o równowartościowym utworze w języku docelowym. Podział zaproponowany przez autorkę wiąże się ze zwróceniem uwagi na dzieło wyjściowe, gdyż wypadkowa tych kodów jest niczym innym jak nośnikiem indywidualnej estetyki danego pisarza. Sama kategoria „Individualästhetik" funkcjonuje zaś w przekładoznawstwie przede wszystkim za sprawą 
Brigitte Schultze (1940-), wybitnej niemieckiej slawistki, która - chcąc przesunąć obiekt zainteresowania z estetyki tłumacza na estetykę oryginału - poddaje pod dyskusję możliwość oddania w tłumaczeniu tego, co najczęściej określa się mianem unikalności pisarza czy jego osobliwego stylu (Schultze 2008) ${ }^{8}$. Według Schultze mówimy zatem o swego rodzaju systemie artystycznych praktyk, składającym się z połączonych ze sobą charakterystycznych elementów poetyki, a nade wszystko powstałym w konkretnym momencie historyczno-biograficznym (Schultze 2008: 11). Ostatnia uwaga koresponduje z teorią znanego austriackiego komparatysty Petera Václava Zimy (1946-), według którego dialogiczna natura przekładu uniemożliwia rozdzielenie go od norm językowych, ideologicznych czy estetycznych. Z kolei owe normy estetyczne, wyjaśnia Zima, z jednej strony zależą od epoki i społeczeństwa twórcy oryginału, natomiast $\mathrm{z}$ drugiej skłaniają tłumacza do kreowania nowych konstrukcji za sprawą swoich interpretacji (Zima 1992: 199). Na tej podstawie można zatem wysnuć wniosek, że to, co w poniższych analizach uznaję za estetykę Szymborskiej, jest w istocie zbiorem jej osobliwego stylu, stosunku do „bliskości” i „obcości” kulturowej, unikalnym napięciem między kontekstualizacją a dekontekstualizacją (Schultze 2005: 863), warstwą językową wiersza oraz jego zakotwiczeniem w konkretnym momencie historycznym, społeczeństwie, tradycji tudzież przestrzeni geograficznej. Zadaniem tłumacza jest zatem rozczytanie, a także przetransponowanie tychże, mając jednocześnie na uwadze kwestie związane z konotacyjnym charakterem poszczególnych wyrazów w obu systemach językowych.

Jedną z najpojemniejszych kategorii, jakie można zastosować przy badaniu elementów kultury w przekładzie, jest kategoria „słów-kluczy” (niem. das Kulturwort, ew. der kulturelle Schlüsselbegriff) 9 . O nich pisała także Anna Wierzbicka, wskazując między innymi na trudności związane $\mathrm{z}$ faktycznym uzasadnieniem dlaczego takie, a nie inne wyrazy można by zawrzeć $\mathrm{w}$ zbiorze określeń charakteryzującym daną kulturę (1997: 15-16). Jedno natomiast jest pewne - za wspólny mianownik dla tych pojęć należy przyjąć ich pierwiastek tożsamościowy (Schultze 2012: 47), za sprawą którego dane słowa poza pewnym kręgiem nie wzbudzą specyficznych skojarzeń lub wielorakości możliwości interpretacyjnych. A zatem słowa-klucze wskazują na korelację między tożsamością narodową, mentalnością, zwyczajami, jak również odniesieniami do kanonicznych dzieł sztuki tego obszaru. Znaczenie tychże jest oczywiście ściśle związane $\mathrm{z}$ aspektem przestrzenno-temporalnym

8 Inne prace oparte o kategorię estetyki indywidualnej: Lukas 2016; Celebańska 2014; Jokiel 2013.

$9 \quad$ Konkretne przykłady funkcjonowania takich pojęć znaleźć można w Schultze 1994 lub w tekście Historia i kultura pod soczewką: kluczowe pojęcia polskiej kultury jako wyzwanie dla tłumacza, gdzie Schultze koncentruje się między innymi na słowach „cham”, „kresy”, „cierpiętnictwo" i „sarmata” (Schultze 1999: 3-22). 
(Schilly 2003: 74), ponieważ słowa-klucze ewoluują, z biegiem czasu nabierają nowych sensów, a niekiedy zmianie podlega również kontekst ich użycia.

Ponieważ duża część kodu kulturowego uwidacznia się w niuansach semiotyczno-symbolicznych (Krysztofiak 2013: 61), tłumacz staje często przed wyzwaniem związanym z odpowiednim podaniem konkretnej informacji swoim czytelnikom. Chcąc jednocześnie zachować wiążący element dominanty utworu i przekazać nową wiedzę odbiorcy, stosuje różnego rodzaju zabiegi. Wiele ze słów-kluczy funkcjonuje jednak jako tzw. inwarianty (Lebiedziński 1989: 125-130), czyli hasła, których usunięcie lub zastąpienie może doprowadzić do poważnego okaleczenia oryginału. Sposób potraktowania wyrazów nacechowanych kulturowo wiąże się innymi słowy $\mathrm{z}$ różnego rodzaju konsekwencjami w wymiarze mikro - na poziomie danego utworu - i w wymiarze makro, tj. wpływając na recepcję twórczości autora w danym kraju. Schultze wymienia kilka możliwych postaw translatorskich wobec słów-kluczy, w tym pominięcie, przekład bezpośredni, substytucja i eksplikacja (2004: 929). Usunięcie kłopotliwego wyrazu jest zapewne najprostsze, ale godzi w tekst wyjściowy, natomiast przełożenie go wprost wydaje się bezcelowe, gdy mamy do czynienia ze zjawiskiem zupełnie obcym w kulturze docelowej (to znaczy nienoszącym znamion internacjonalnych). Szerszy opis danego słowa-klucza zaburza z kolei oryginalną formę i strukturę dzieła, dlatego innym rozwiązaniem są również parateksty, najczęściej komentarze czy przypisy ${ }^{10}$. W antologii Livet er den eneste måten Kjelstrup posiłkuje się przypisem raptem jeden raz, gdzie w wierszu $W$ dyliżansie (Tutaj, 2009) pojawia się postać Juliusza Słowackiego. Tłumacz informuje, że „był to polski poeta i dramaturg, żyjący w latach 1809-1849” (Szymborska, Kjelstrup 2013: 111-112), i choć uznajemy to za cenną uwagę, mówi ona niewiele o faktycznym kontekście oraz przesłaniu utworu. U Selberga znajdziemy natomiast na samym końcu zbioru siedem wyjaśnień, ale tylko jedno z nich bezpośrednio odnosi się do tradycji polskiej (Szymborska, Selberg 1996: 151). Mowa tu o utworze Moment $w$ Troi (Sól, 1962), nawiązującym do tragedii Jana Kochanowskiego (1530-1584) pt. Odprawa posłów greckich (wyd. 1578).

\section{Szymborskiej zabawy z kulturą po norwesku}

Zaprezentowane poniżej wiersze nie poruszają wszystkich zjawisk kulturowych, zawartych w obu antologiach. Analizy mają na celu jedynie wskazanie kilku ciekawszych fragmentów i sposobów przedstawienia słów-kluczy przez norweskich tłumaczy. Począwszy od wydania z 1996 roku pochylimy się przede wszystkim nad utworami $Z$ nieodbytej wyprawy $w$ Himalaje/Fra en aldri

10 Więcej o roli komentarzy w przekładzie symboli kultury pisze Horst Turk 1992, zob. także Tokarz 2017. 
foretatt Himalaya-ekspedisjon (Wołanie do Yeti, 1957), Wieczór autorski/Opplesningsaften (Sól, 1962) oraz Nieczytanie/Ikke-lesning (Tutaj, 2009).

Na wstępie watro jednak zaznaczyć, że zabawy z konwencjami, utartymi symbolami oraz częste dialogi intertekstualne nie służą u Szymborskiej zaznaczeniu swojej tożsamości narodowej. Wręcz przeciwnie, to poezja na wskroś uniwersalna, gdzie człowiek staje na równi z kamieniem czy źdźbłem trawy. Na próżno szukać tu typowej dla polskiej liryki powojennej martyrologii czy bohaterskich laudacji, bo tak naprawdę tylko codzienność, proste prawdy, zachwyt nad konstrukcją świata są nam najbliższe - z nimi należy się oswajać. Niezwykła więź, jaka wytwarza się dzięki temu między podmiotem lirycznym a czytelnikiem, nie byłaby jednak tak silna, gdyby nie humor i ironia autorki. One, wraz z zamiłowaniem noblistki do paradoksu oraz przeciwieństw (Nyczek 2000: 6-15), pozwalają odbiorcy poznawać wspólne nam wszystkim uniwersum. Oderwanie od normatywnych zasad gramatycznych oraz syntaktycznych, łamanie frazeologizmów, zaskakujące metafory, personifikacje, język potoczny - wszystko to stwarza „rzeczywistość bardziej rzeczywistą" niż ta, w której z pozoru żyjemy (Borkowska 1991: 112-126). Podmiot Szymborskiej zdaje się hołdować zasadzie reductio ad absurdum, gdzie nonsens, hiperbole, łączenie stylu wysokiego $\mathrm{z}$ niskim przemawiają nie do intelektu, a do ludzkiej intuicji, dzięki czemu możliwe staje się poznanie kwintesencji rzeczy (Huxley 1989: 59). Jeśli zaś mowa o powadze (auto)ironii i humorze w stylu sokratejskim (Szymborska 1973: 12, 181), ich połączenie jest autentyczną postawą, a wręcz bronią przed pułapkami egzystencji (Gralewicz-Wolny 2014: 113-114, 161), a - jak powiedział Søren Kirkegaard (1813-1855) - ironia jest zarówno formą kary, objawia prawdę, świadczy o odwadze, jak i uwodzi (Kirkegaard, Socrates 1841: 346-349). Istotnie, te środki wyrazu kuszą czytelnika, wzbudzają ciekawość, a na dodatek skłaniają do nowego typu przemyśleń (Wiatr 1996: 136). Być może właśnie dlatego Szymborska $\mathrm{z}$ taką swobodą obnaża ludzkie słabości, wspierając się przy tym odniesieniami do wielkich nazwisk, dzieł i symboli. Z drugiej strony za sprawą osadzenia utworów w konkretnym kontekście kulturowym autorka pozwala odbiorcy „poczuć się jak w domu”, to forma identyfikacji, zbliżenia oraz nawiązywania więzi. Pozostaje zatem pytanie czy przekład wymaga ingerencji bądź zmiany takiej literackiej rzeczywistości?

Wszystkie wyżej wymienione elementy estetyki Szymborskiej są obecne w omawianych tu wierszach, ale dwa pierwsze tytuły postawiły Selberga przed szczególnym wyzwaniem, ponieważ znajdziemy w nich nie tylko odniesienia do polskiej literatury, ale także polskiego folkloru. Dodatkową trudnością stają się w tym momencie również gry słowne, stylizacja, a niekiedy potoczność języka. Utwór $Z$ nieodbytej wyprawy w Himalaje zawiera kilka słów-kluczy, z którymi tłumacz poradził sobie następująco: 


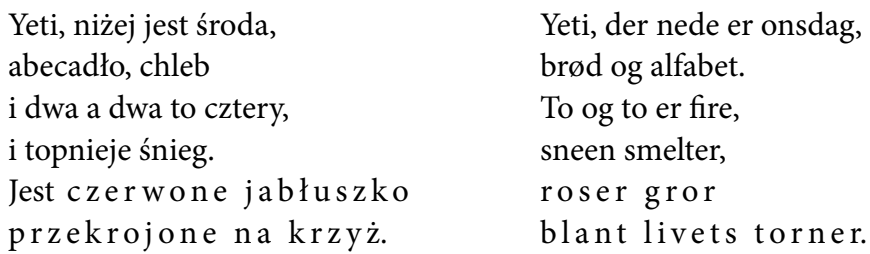

$\mathrm{W}$ przytoczonej tu drugiej strofie napotykamy $\mathrm{w}$ oryginale na wpleciony $\mathrm{w}$ enumerację cytat $\mathrm{z}$ polskiej piosenki ludowej pt. Czerwone jabłuszko (Wawiłow, Usenko, red., 1987). Podmiot uznaje dwa ostatnie wersy za oczywisty element codzienności, próbując skusić Yeti za pomocą bezpośrednich apostrof do opuszczenia swojej kryjówki. Zaproszenie do świata ludzkiego opiera się w całym utworze na wymienianiu między innymi: zasad logicznych, pór roku, jedzenia i wskazaniu na emocjonalną naturę człowieka. Według badaczy słowa polskiej piosenki mają wręcz magiczny charakter, są powszechnie znane, a mnogość konotacji, jakie budzą wśród czytelników, wiąże się bezpośrednio z polską kulturą (Kania 1998). Selberg zastępuje tę frazę słowami „róże rosną / pośród cierni życia”, co nijak ma się do wyjściowej koncepcji autorki. Jednakże wersy te nawiązują do twórczości powszechnie znanego w Norwegii pastora i poety ze Stavanger, Jensa Zetlitza (1761-1821), który w utworze Mine loengsler (Moje tęsknoty, 1789) używa bardzo podobnego sformułowania: „Rzekłem do obojga; / «Pośród cierni życia róże rosną; / czerpcie radość z cnoty źródła / a Bóg was umiłuje»"11 (Zetlitz 1886: 32-33). Inspiracją dla Zetlitza było prawdopodobnie tłumaczenie Biblii Marcina Lutra (1486-1546), a dokładnie fragment Pieśni nad Pieśniami ${ }^{12}$. Selberg zamienił zatem element obcy z oryginału i przystosował go do własnej kultury docelowej.

Na tym jednak nie koniec trudności, ponieważ Szymborska powołuje się z jednej strony na powszechnie znanego Szekspira (piąta strofa), a z drugiej na tajemniczą postać Twardowskiego:

Tu - ni księżyc, ni ziemia i łzy zamarzają.

O Yeti Półtwardowski, zastanów się, wróć!
Her er hverken måne eller jord.

Tårene fryser.

O Yeti, h a lv mån e b o e r, tenk deg om, kom tilbake!

Legenda głosi, że Twardowski był szlachcicem żyjącym w XVI wieku, który paktował z diabłem. Ponieważ Twardowskiemu udało się przechytrzyć rokitę, ten upuścił śmiertelnika w drodze do piekła i tak właśnie bohater wylądował na księżycu,

11 W oryginale brzmią one następująco: „Jeg sagde til dem begge to; / «Blandt Livets Torne Roser gro; / af Dydens Kilde Glæden øs, / og Gud skal eder ynde»”. Przekład na język polski jest tłumaczeniem filologicznym autorki artykułu.

12 Por. Høys 2,1-2: „Jeg er Sarons blomst, en rose i dalen. Som en rose blant torner, slik er min elskede blant de unge kvinner". 
gdzie siedzi po dziś dzień. Historia Twardowskiego ma wiele wspólnego z Faustem (1801/1833) Johanna Wolfganga Goethego (1749-1832), dlatego w obiegu funkcjonuje również określenie „polski Faust” (Hahn 1913) ${ }^{13}$. Selberg całkowicie rezygnuje $\mathrm{z}$ antroponimu Twardowski, tworząc neologizm na podstawie polskiego członu pół- (halv-) i złożonego rzeczownika en måneboer, czyli mieszkańca księżyca. Podobnym objaśnieniem posłużył się również Bodegård, nazywając Twardowskiego halvvägs mångubbe (dosł. w połowie księżycowy starzec; Szymborska 2003: 54), a także para Barańczak-Cavanagh (Szymborska 1997: 11), gdzie polski szlachcic staje się półksiężycowym człowiekiem (semi-moonman).

W utworze Wieczór autorski podmiot liryczny, najprawdopodobniej poeta, przygotowuje się do odczytu swoich tekstów, obserwując przybyłych. Skłania go to do kilku refleksji: przyszło raptem dwunastu słuchaczy - część to znajomi, część nakłoniła do tego pogoda, reszta to kilka omdlałych pań i przysypiający staruszek. Stąd porównanie, że bycie literatem jest jak bycie bokserem, to walka o (za)istnienie, jednak nie przy pomocy muskulatury, a - słów. W końcu pada stwierdzenie:

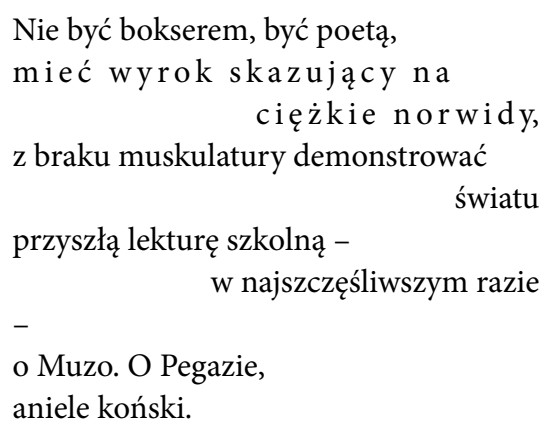

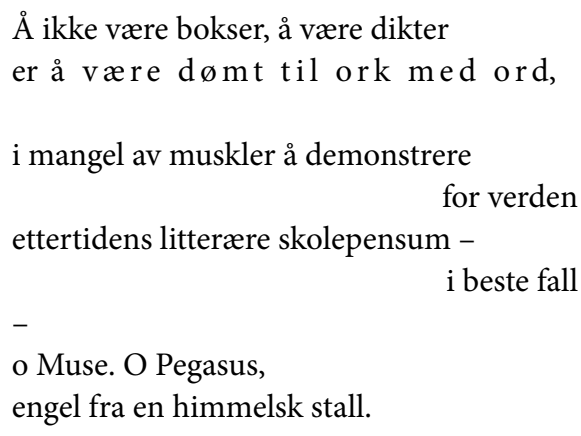

Å ikke være bokser, å være dikter er å være dømt til ork med ord, i mangel av muskler å demonstrere ettertidens litterære skolepensum -

o Muse. O Pegasus, engel fra en himmelsk stall.

„Wyrok skazujący na ciężkie norwidy” jest złożonym pojęciem-kluczem. Po pierwsze Szymborska ingeruje w stały zwrot „być skazanym na ciężkie roboty”, zastępując rzeczownik "roboty” antroponimicznym neologizmem "norwidy”, użytym w liczbie mnogiej i pisanym małą literą. Niełatwe życie oraz powszechnie uznana za trudną twórczość Cypriana Kamila Norwida (1821-1883) są dla polskiego odbiorcy oczywistym punktem wyjścia dla zrozumienia tej syntagmy (Wyka 1989), natomiast aluzja ta nic nie znaczy dla odbiorcy norweskiego. Stąd też Selberg rezygnuje z przypisu i nawiązuje wprost do interpretacji oryginalnej propozycji Szymborskiej - poeta jest tu „skazany na orkę ze słowami” (å vere dømt til ork med ord). Mimo że przesłanie w obu tekstach pozostaje takie samo, przekład traci na wyjściowej kreatywności, a także pomija element intertekstualny. Zatraca się także zakorzenienie w rodzimym kręgu kulturowym autorki, które

13 W niemieckim tłumaczeniu tego wiersza Dedecius używa określenia „Halbfaust” (Szymborska 1997a: 69). Więcej o tym pisze Szerszunowicz (2014). 
w odniesieniu do tematyki całego utworu dodaje autoironicznego wyrazu. Zmianie ulega również epitet „koński” anioł (u Selberga to anioł z niebiańskiej stajni), ale rozbudowanie tej frazy $\mathrm{w}$ połączeniu $\mathrm{z}$ uniwersalną symboliką mitycznego Pegaza w żaden sposób nie wpływa na oryginał. Zyskuje przez to jednak norweski tekst, gdyż rzeczowniki fall (ze zwrotu „w najlepszym razie”) i stall zaskakująco tworzą rym męski.

U Kjelstrupa mamy ponadto do czynienia $\mathrm{z}$ innym ważnym polskim literatem. Utwór Nieczytanie w ironiczny sposób ukazuje upadek czytelnictwa i znajomości literatury we współczesnym świecie, a Szymborska obrazuje to dzięki zestawieniu ze sobą pisarzy Marcela Prousta (1871-1922) oraz Bolesława Prusa (1847-1912). Podmiot słyszał wprawdzie o tym pierwszym, utyskując, że do siedmiu tomów jego powieści - przypuszczalnie W poszukiwaniu straconego czasu (1913-1927) nie dodają pilota do telewizora. W kluczowej dla utworu strofie czytamy:

Siedem tomów - litości.

Nie dałoby się tego streścić, skrócić,

albo najlepiej pokazać w obrazkach.

Szedł kiedyś serial pt. Lalka,

ale bratowa mówi, że kogoś
Syv bind - gud bedre.

Kunne ikke noen kortet dem ned litt, lagd et resymé, eller enda bedre: en versjon i bilder. Det gikk en gang en serie som het Dukken, men svigerinnen min sier at den var av en annen på P.

Rozczarowane i zdezorientowane ja liryczne stwierdza, że najbardziej przystępną formą zapoznania się z literaturą jest jej ekranizacja, a najlepiej film akcji. Bratowa wspomina, co prawda, „kogoś innego na P.”, ale to nie Proust. Próba wyjaśnienia, kim jest ów tajemniczy autor, kończy się jednak pomieszaniem anegdot $\mathrm{z}$ życia obu pisarzy ${ }^{14}$. Jedyne, co naprowadza czytelnika na jednego $\mathrm{z}$ ważniejszych polskich autorów, to wspomniany serial Lalka $(1977)^{15}$, co z punktu widzenia przesłania wiersza jest kluczową informacją. Zdemaskowany przez czytelnika, ale zapomniany przed podmiot „inny P.”, ukazuje, jak dalece klasyczne dzieła literatury pięknej nie trafiają do współczesnego odbiorcy. To ubrana w zabawną ironię krytyka przede wszystkim rodzimej kultury i polskiego społeczeństwa, choć niestety mało czytelna dla odbiorcy norweskojęzycznego. Tytuł Dukken (pl. lalka) budzi w Norwegii oczywiste skojarzenie z dramatem Henryka Ibsena (1828-1906) pt. Et Dukkehjem $(1879)^{16}$, natomiast nieświadoma aluzja do norweskiego pisarza

\footnotetext{
14 By zrozumieć tę grę faktów, warto powołać się na: Currey (2015).

15 Powieść Lalka została opublikowana w formie książkowej w 1890 roku.

16 W Polsce znanym na przykład pod tytułem Nora (tłum. z 2006 roku, wydawnictwo Czuły barbarzyńca) i Dom lalki (Nora) (tłum. z 2014 roku, wydawnictwo Czuły barbarzyńca). Autorką obu tłumaczeń jest Anna Marciniakówna.
} 
pozbawia oryginalny wiersz humoru oraz dodatkowej gry słownej między nazwiskami „na P.” Kjelstrup w żaden sposób nie wyjaśnia, do kogo referuje tekst wyjściowy, dlatego duża część oryginalnego uroku w przekładzie po prostu zanika. Choć konsumpcyjna rzeczywistość jest zjawiskiem powszechnym bez względu na szerokość geograficzną, podobnie jak potoczność języka, obecna także w tłumaczeniu, pozbawienie tego utworu aliteracji, a przede wszystkim kluczowej puenty poprzez bezpośrednie zaadaptowanie danego zjawiska zdaje się najprostszym, ale być może niekoniecznie przemyślanym rozwiązaniem.

\section{Słowo końcowe}

Czesław Miłosz (1911-2004) napisał kiedyś o Szymborskiej, że jej „ja” jest ascetyczne, nieskłonne do osobistych wynurzeń i nieczujące potrzeby dzielenia się swoim wnętrzem. Podobnie jest $\mathrm{z}$ jej głosem poety-człowieka, który opowiada po prostu o całej ludzkości (Miłosz 1996: 9) i starych jak świat ludowych mądrościach (Kornhauser 2002: 36). Nie oznacza to jednak, że ta uniwersalna w swoim przesłaniu literatura nie zawiera kodów kulturowych, których złamanie staje się dla tłumaczy najtrudniejszym wyzwaniem. Leszek Szaruga zauważył, że „przypadkowy Grześ” i Marek Aureliusz (2014: 121-180) są u Szymborskiej tak samo ważni - obaj należą do lirycznego uniwersum autorki (Szaruga 2014: 83). Zaprezentowane powyżej przykłady przeniesienia słów-kluczy na grunt norweski pokazały, że mimo zastosowania różnych zabiegów translatorskich nie istnieje wspólne dla wszystkich, dobre rozwiązanie. Hanne Ørstavik (1969-), jedna z najważniejszych współczesnych pisarek w Norwegii, scharakteryzowała przekład tymi słowami:

Przekład zawsze jest czymś innym. Różnym. Odmiennym. [...] Dzieje się to w przestrzeni między dwoma tekstami. Coś się traci lub zyskuje. Albo daje. Ponieważ język rozgrywa się w nas, także w tłumaczeniu - jesteśmy wewnątrz tego wszystkiego, a nie poza (2006: 17-18).

Pomimo różnic językowych i kulturowych poezja Szymborskiej pozostanie w kanonie literatury światowej dopóty, dopóki nadal będzie leczyć ludzi z ich arogancji i hipokryzji (Boniecki 2015: 18), a o jej wartości świadczy choćby przyznana pisarce Nagroda Nobla. Być może odbędzie się to kosztem braku przybliżenia obcojęzycznym czytelnikom sylwetek Norwida, Słowackiego czy fenomenu schabowego ${ }^{17}$, ale skoro „przekład zawsze jest czymś innym”, nie zmieni tego nawet kod kulturowy.

17 Szymborska używa określenia „denat schabowy” w wierszu Przymus (Wystarczy, 2012), nawiązując tym samym w żartobliwy sposób do Czesława Miłosza (Bikont, Szczęsna 2004). Więcej o kulinarnych aspektach norweskich przekładów Szymborskiej: Wilkus-Wyrwa 2019: 173-175. 
Bibliografia

Aarnes, A. (1977). Littercert leksikon begreper og betegnelser. Teori - Kritikk - Historie. Oslo: Kunnskapsforlaget.

Barańczak, S. (1994). Ocalone w tłumaczeniu szkice o warsztacie tłumacza poezji $z$ dołaczeniem małej antologii przekładów, Kraków: Wydawnictwo a5.

Baubeta, P.A.O. de. (2007). The Anthology in Portugal. A New Approach to the History of Portuguese Literature in the Twentieth Century. Bern: Peter Lang.

Bikont, A., Szczęsna, J. (2004). Onieśmielenie Wisławy Szymborskiej. Poetka pisze o Czesławie Miłoszu. Wyborcza.pl, 17.01., http://wyborcza.pl/1,75410,1862670.html [dostęp: 15.04.2019].

Bodegård, A. (2003). Wisława - wirówka?. Przekładaniec 1 (10).

Bodegård, A. (2012). A. Bodegard: Szymborska przed moimi tłumaczeniami była znana w Szwecji. Rozm. przepr. D. Nowicka. Nowa Trybuna Opolska, 5.05., https://nto.pl/anders-bodegard-szymborska-przed-moimi-tlumaczeniami-byla-znana-w-szwecji/ar/4495649 [dostęp: 17.11.2018].

Bodegård, A. (2014). Wolę umarłych, bo z nimi nie ma żadnego problemu. Wiadomości ZAiKSu 7.

Boniecki, A. (2015). Abonent chwilowo nieosiągalny. Kraków: Wydawnictwo WAM.

Borkowska, G. (1991). Kieffer albo zakończenie sporu o obrazy. Teksty drugie 10 (4).

Celebańska, E. (2014). Marek Hlaskos vulgäre Individualästhetik als Übersetzungsproblem. Die kontrastive Translatationsanalyse der Erzählung Ósmy dzien tygodnia und deren deutschen Übersetzung von Vera Cerny. München: GRIN Verlag.

Chojnowski, P. (2005). Zur Strategie und Poetik des Übersetzens: eine Untersuchung der Anthologien zur polnischen Lyrik von Karl Dedecius. Berlin: Frank \& Timme.

Currey, M. (2015). Marcel Proust (1871-1922). W: M. Currey. Codzienne rytuały. Jak pracuja wielkie umysty. Tłum. A. Napiórska. Warszawa: Wydawnictwo WAB.

Dybdo, T. (1996). Jan Garbarek - det åpne roms estetikk. Oslo: Pax Forlag A/S.

Eßmann, H. (1992). Übersetzungsanthologien: eine Typologie und eine Untersuchung am Beispiel der amerikanischen Versdichtung in deutschsprachigen Anthologien, 1920-1960. Frankfurt am Main/New York: Peter Lang.

Frank, A.P., Eßmann, H. (1990). Translation Anthologies: A Paradigamatic Medium of International Literary Transfer. Amerikastudien 5 (35).

Fyllingsnes, O., Kjelstrup, C. (2013). Ei svært elskverdig dame. Dag og Tid 17.

Gralewicz-Wolny, I. (2014). Poetka i Świat. Studia i szkice o twórczości Wisławy Szymborskiej. Katowice: Wydawnictwo Uniwersytetu Śląskiego.

Hahn, W. (1913). „Twardowski, der polnische Faust”. Münster: Wilhelm Leppelmann.

Huxley, A. (1989). Filozofia wieczysta. Tłum. J. Prokopiuk, K. Środa. Warszawa: Pusty Obłok.

Januszewska-Skreiberg, J. (2001). Od Ibsena do Twardowskiego. Norwesko-polskie pejzaże kulturalne. Warszawa: Interlibro.

Januszewska-Skreiberg, J. (2011). M. Ułas (red.). Sercem w dwóch krajach. Norwesko-polskie pejzaże kulturalne. Inowrocław: FISO.

Jokiel, M. (2013). Obcość i niekonwencjonalność prozy a przekład. Arno Schmidt i Reinhard Jirgl. Przekładaniec 27.

Kania, I. (1998). Perypetie czerwonego jabłuszka i pięściowego tłuka, czyli garść uwag o przekładach poezji Wisławy Szymborskiej na angielski, niemiecki i francuski. Dekada Literacka $8 / 9$. 
Kirkegaard, S., Socrates. (1841). Om Begrebet Ironi med stadigt Hensyn til Socrates. Kjøbenhavn: P.G. Philipsens Forlag.

Kornhauser, J. (2002). Zwyczajne niebo Wisławy Szymborskiej. Kwartalnik Artystyczny 2.

Krysztofiak, M. (2013). Einführung in die Übersetzungskultur. Frankfurt am Main: Peter Lang Edition.

Lebiedziński, H. (1989). Przekładoznawstwo ogólne wobec teorii enroi. Warszawa: Państwowe Wydawnictwo Naukowe.

Lothe, J., Refsum, C., Solberg, U. (1997). Litteraturvitenskapelig leksikon. Oslo: Kunnskapsforlaget. Lukas, K. (2016). Bolesław Leśmian und Bruno Schulz in deutschen Übersetzungen. Übersetzer im Spannungsfeld von Kultur, Individualästhetik und (Sprach-)Philosophie. W: S. Schahadat, Š. Zbytovský (edas.). Übersetzungslandschaften. Themen und Akteure der Literaturübersetzung in Ost- und Mitteleuropa. Bielefeld: Transcript Verlag.

Miłosz, C. (1996). Poezja jako świadomość. W: E. Balcerzan i in., Szymborska. Szkice. Warszawa: Open.

Morken, C. (2015). Fredsbarnet som ble verdensberømt. Sør-Trøndelag. 9.05, https://www.avisa-st.no/nyheter/article10941535.ece [dostęp: 1.12.2018].

Nag, M. (1997). H.E. Aarek (ed.). Tverr-snitt: litteraturhistorie, kulturhistorie, prosalyrikk: festskrift til Martin Nag på 70 års dagen 30. juli 1997. Jørpeland: Kvekerforlaget.

Neuger, L. (1991). Wysławianie Wisławy Szymborskiej - na marginesie przekładów na język szwedzki Andersa Bodegårda. Teksty Drugie 4 (10).

Nilsson, S.A.L. (2012). Kod kulturowy a przekład. Na podstawie wybranych utworów Astrid Lindgren $i$ ich polskich przekładów. Stockholm: Stockholms Universitet.

Nyczek, T. (2000). 22 x Szymborska. Gdańsk: Tower Press.

Ørstavik, H. (2006). Om oversettelse utifra erfaringen av å bli oversatt. Norske Kritikeres Fagtidsskrift.

Pforte, D. (1970). Ein Beitrag zu ihrer Theorie. W: J. Bark, D. Pforte (eds.), Die deutschsprachige Anthologie: Ein Beitrag zu ihrer Theorie und eine Auswahlbibliographie des Zeitraums 18001950. Frankfurt am Main: Klostermann.

Schilly, U.B. (2003). Carmen spricht deutsch: literarische Übersetzung als interkulturelle Kommunikation am Beispiel des Werkes von Miguel Delibes. Würzburg: Königshausen \& Neumann.

Schultze, B. (1994). Polnische Schlüsselbegriffe - als Verstehensproblem, als Aufgabe für Übersetzer. Convinium. Germanistischens Jahrbuch 2.

Schultze, B. (1999). Historia i kultura pod soczewką: kluczowe pojęcia polskiej kultury jako wyzwanie dla tłumacza. W: M. Sugiera (red.). Perspektywy polonistyczne i komparatystyczne. Kraków: Universitas.

Schultze, B. (2004). Kulturelle Schlüsselbegriffe und Kulturwörter in Übersetzungen fiktionaler und weiterer. W: P.A. Frank, N. Greiner, T. Hermans (eds.). Übersetzung, translation, traduction: ein internationales Handbuch zur Übersetzungsforschung. Vol. 1. Berlin-New York: Walter de Gruyter.

Schultze, B. (2005). Kontexte in der literarischen Übersetzung. W: H. Kittel, A.P. Frank (eds.). Übersetzung. Ein internationales Handbuch zur Übersetzungsforschung. Vol. 1. Teilbd. Berlin, New York: De Gruyter.

Schultze, B. (2008). Individualästhetik als Beobachtungsort literarischer Übersetzungen. W: M. Krysztofiak (ed.). Posener Beiträge zur Germanistik. Ästhetik und Kulturwandel in der Übersetzung. Frankfurt am Main: Peter Lang. 
Schultze, B. (2012). Sprachenpaare im Blickpunkt: Schnittstellen von Sprache und Kultur in Dramenübersetzungen. W: K. Lukas, I. Olszewska, M. Turska (hrsg.). Translation im Spannungsfeld der „cultural turns”. Frankfurt am Main: Peter Lang.

Szaruga, L. (2014). „Mały Grześ z naprzeciwka i Marek Aureliusz”. Kwartalnik Artystyczny 1.

Szerszunowicz, J. (2014). Między adaptacją a egzotyzacją: odwołania do tekstów kultury polskiej jako kategoria lakunarna w przekładach. Białostockie Archiwum Językowe 14.

Szymborska, W. (1957). Wołanie do Yeti. Kraków: Wydawnictwo Literackie.

Szymborska, W. (1962). Sól. Warszawa: Państwowy Instytut Wydawniczy.

Szymborska, W. (1973). Lektury nadobowiązkowe. Kraków: Wydawnictwo Literackie.

Szymborska, W. (1996). Utsikt med et sandkorn. Transl. O.M. Selberg. Oslo: Solum.

Szymborska, W. (1997a). Sto wierszy. Sto pociech/ Hundert Gedichte. Hundert Freuden. Tłum. K. Dedecius. Kraków: Wydawnictwo Literackie.

Szymborska, W. (1997b). Nothing Twice. Selected Poems. Tłum. S. Barańczak, C. Cavanagh. Kraków: Wydawnictwo Literackie.

Szymborska, W. (2003). Dikter 1945-2002. Transl. A. Bodegård. Stockholm: FIB:S Lyrikklubb.

Szymborska, W. (2009). Tutaj. Warszawa: Wydawnictwo Znak.

Szymborska, W. (2013). Livet er den eneste måten. Dikt 2002-2012. Transl. C. Kjelstrup. Oslo: Tiden Norsk Forlag.

Textorten. W: A.P. Frank, N. Greiner, T. Hermans, H. Kittel, W. Koller, J. Lambert, F. Paul (eds.). Übersetzung, translation, traduction: ein internationales Handbuch zur Übersetzungsforschung. Vol. 1. Berlin-New York: Walter de Gruyter.

Tokarz, B. (2017). Parateksty jako wyraz koncepcji przekładu. W: M. Gawlak (red.). Przekłady literatur Słowiańskich. T. 8, cz. 1. Katowice: Uniwersytet Śląski.

Turk, H. (1990). Alienität und Alterität als Schlüsselbegriffe einer Kultursemantik. Zum Fremdheitsbegriff der Übersetzungsforschung. Jahrbuch für Internationale Germanistik 1 (22).

Turk, H. (1992). Übersetzung ohne Kommentar. Kulturelle Schlüsselbegriffe und kontroverser. Kulturbegriff am Beispiel von Goytisolos „Reivindicación des Conde don Julián”. W: F. Lönker (hrsg.). Die literarische Übersetzung als Medium der Fremderfahrung. Berlin: Erich Schmidt Verlag.

Vold, J.E. (1998). Storytellers. En begrunnet antologi. Oslo: Gyldendal.

Wawiłow, D., Usenko, O. (red.). (1987). Czerwone jabłuszko. Wierszyki i piosenki ludowe. Warszawa: Nasza Księgarnia.

Wiatr, A. (1996). Syzyf poezji w piekle współczesności. Rzecz o Wisławie Szymborskiej. Warszawa: Wydawnictwo Kram.

Wierzbicka, A. (1997). Understanding Cultures through Their Key Words. English, Russian, Polish, German and Japanese. New York-Oxford: Oxford University Press.

Wilkus-Wyrwa, A. (2019). Forfatterens individuelle estetikk i gjendiktning. Wisława Szymborska og Czesław Miłosz i norske oversettelser. Berlin: Peter Lang.

Wojtasiewicz, O. (1957). Wstęp do teorii tłumaczenia. Wrocław-Warszawa: Zakład im. Ossolińskich.

Wyka, K. (1989). Cyprian Norwid. Studia, artykuły, recenzje. Kraków: Wydawnictwo Literackie. Zetlitz, J. (1886). Udvalg af Jens Zetlitz' Digte. J. Utheim (hrsg.). København: Gyldendal.

Zima, P.V. (1992). Komparatistik. Einführung in die Vergleichende Literaturwissenschaft. Tübingen: Francke Verlag Tübingen. 